Trabajo recibido el 22 de febrero de 2017 y aprobado el 6 de mayo de 2017

\title{
La notificación legal de la demanda debe realizarse dentro del plazo de prescripción de la acción respectiva para que pueda entenderse interrumpida civilmente la prescripción
}

Ruperto PinOchet Olave*

RESUMEN

Se comenta la sentencia de la Corte Suprema, rol № 6900-2015, de 31 de mayo de 2016, que ha sostenido que la notificación legal de la demanda puede hacerse fuera del plazo de prescripción lográndose de igual modo el efecto de interrumpir la prescripción. Se exponen los argumentos del fallo, desestimándolos, argumentando las razones por las que se estima correcta la tesis contraria. También se alude a la sentencia de la Corte Suprema, rol № 55077-20169, de 9 noviembre de 2016, que alejándose de lo sostenido en la primera de ellas comentada, retoma lo que ha sido la doctrina y jurisprudencia mayoritaria en Chile, en el sentido de que para interrumpir civilmente la prescripción la notificación legal de la demanda debe hacerse dentro del plazo interruptivo de la acción respectiva de que se trate.

\section{Sentencia de la Corte Suprema, rol No 6900-2015, de 31 de mayo de 2016}

En autos rol No 838-2012 seguidos ante el $2^{\circ}$ Juzgado Civil de San Fernando, juicio sumario sobre acción reivindicatoria especial del decreto ley $\mathrm{N}^{\circ} 2.695$, caratulados "Vargas Cerpa, Luis Alberto y otros con Marmolejo Fuenzalida, Carlos", por sentencia de veintitrés de mayo de dos mil catorce, de fojas 279 y siguientes, se acogió en forma parcial la demanda ordenando la cancelación de la inscripción de dominio a favor del demandado, sin costas.

Recurrido el fallo en apelación, la Corte de Apelaciones de Rancagua, por resolución de dieciséis de abril de dos mil quince, de fojas 322 y siguientes, rechazó la excepción de prescripción interpuesta en segunda instancia y confirmó la sentencia.

En contra de esta última decisión, el demandado dedujo recurso de casación en el fondo. Entre los argumentos expuestos, el recurrente manifiesta que la sentencia ha incurrido en infracción de los artículos 15, 16 y 26 del decreto ley N².695, y los artículos 22, 2503 y 2523 del Código Civil. En

\footnotetext{
* Profesor de Derecho civil y Director del Departamento de Derecho Privado y Ciencias del Derecho de la Universidad de Talca. Doctor en Derecho civil por la Universidad de Barcelona. Socio en Pinochet \& Concha Abogados, www.bonafides.cl, Talca. Correo electrónico: rpinoche@utalca.cl.
} 
relación al primer grupo de normas infringidas que contempla el decreto ley $N^{\circ} 2.695$, el recurrente indica que la sentencia recurrida yerra al asimilar el concepto "deducir" que utiliza el artículo 26 del decreto ley № 2.695 con una caducidad, y agrega que "cuando se refiere en el Considerando Noveno a deducir, lo que en realidad describe es un plazo de caducidad para presentar la demanda y no un plazo de prescripción extintiva". De esta manera confunde, señala el recurrente, la prescripción extintiva con la caducidad. Relaciona el yerro recién indicado con los artículos 15 y 16 del mismo cuerpo normativo, los cuales quedarían sin aplicación al seguirse la interpretación otorgada por la sentencia impugnada. En relación a las reglas previstas en el Código Civil, el recurrente manifiesta que hay contravención al artículo 22 al alterarse la armonía en la hermenéutica de los artículos $2503 \mathrm{~N}^{\circ} 1$ y $2523 \mathrm{~N}^{\circ} 2$, cuya aplicación debe llevarse a cabo en forma sistemática con lo previsto en el artículo 26 del referido decreto ley № 2.695.

Para entender el asunto debemos tener en cuenta que el artículo 26 del citado decreto ley $N^{\circ} 2.695$ señala que, sin perjuicio de lo dispuesto en el artículo 19, los terceros podrán, dentro del plazo de un año, contado desde la fecha de la inscripción del inmueble practicada por resolución administrativa o judicial, deducir ante el tribunal señalado en el artículo 20 las acciones de dominio que estimen asistirles, en tanto que el artículo 15 del mismo cuerpo legal dispone que la resolución del Servicio que acoja la solicitud se considerará como justo título. Una vez practicada su inscripción en el Registro del Conservador de Bienes Raíces, el interesado adquirirá la calidad de poseedor regular del inmueble para todos los efectos legales, aunque existieren en favor de otras personas inscripciones que no hubieran sido materialmente canceladas. Transcurrido un año completo de posesión inscrita no interrumpida, contado desde la fecha de la inscripción del interesado se hará dueño del inmueble por prescripción, la que no se suspenderá en caso alguno.

Para cerrar el círculo, el artículo 16 del señalado decreto ley № 2.695 señala que como consecuencia de lo dispuesto en el artículo precedente, expirado el plazo de un año a que esa disposición se refiere, prescribirán las acciones emanadas de los derechos reales de dominio, usufructo, uso o habitación, servidumbres activas y el de hipotecas relativos al inmueble inscrito de acuerdo con la presente ley.

Respecto a la situación fáctica del proceso, la Corte Suprema, en el considerando segundo del fallo comentado, dio por establecidos los siguientes hechos:

a. Que el demandado regularizó el inmueble disputado conforme al decreto ley $N^{\circ} 2.695$ mediante resolución exenta № 3.306, de 22 de julio de 2011, del Ministerio de Bienes Nacionales, la cual fue inscrita a nombre del demandado 
a fojas 49, № 49, del Registro de Propiedad del Conservador de Bienes Raíces de San Fernando, con fecha 14 de julio de 2011.

b. Que la demanda, consistente en acción de dominio especial del artículo 26 del decreto ley № 2.695, fue interpuesta con fecha 6 de julio de 2012.

c. Que la referida demanda fue notificada al demandado con fecha 17 de julio de 2012.

d. Que el demandado interpuso, a fojas 318, excepción de prescripción extintiva por haber transcurrido un año desde la inscripción a su favor y la notificación de la referida demanda.

Explica el considerando tercero, que no existe duda que transcurrió más de un año entre la inscripción de la resolución que regularizó el inmueble a favor del demandado -14 de julio de 2011-y la notificación de la demanda de acción especial de dominio prevista en el artículo 26 del decreto ley $N^{\circ} 2.695-17$ de julio de 2012-. También, que existe certeza que no había transcurrido ese término entre la indicada inscripción -22 de julio de 2011-y la presentación de la demanda -6 de julio de 2012-.

La sentencia recurrida entendió que había operado la interrupción civil de la prescripción por la mera presentación de la demanda, sin que fuere necesaria la notificación de la misma. Para alcanzar esta conclusión hace aplicable a la acción deducida en autos las reglas de la prescripción de corto tiempo, en particular lo previsto en el artículo 2523 del Código Civil, conforme al cual la interrupción civil opera "desde que interviene requerimiento", lo que asimila a la presentación de la demanda.

En el considerando cuarto se realizan dos importantes aclaraciones, las que compartimos. En primer lugar, se explica que el artículo 2523, si bien establece que la interrupción opera por el mero requerimiento, lo que puede asimilarse a la demanda judicial, no resulta aplicable en la especie, quedando limitado su ámbito de aplicación a las acciones previstas en los ya reproducidos artículos 2521 y 2522 del mismo Código, acciones que prescriben en corto tiempo ${ }^{1}$, como se sabe, entre las cuales no se encuentra incluida la acción de dominio especial del artículo 26 del decreto ley No 2.695.

En segundo lugar, señala la Corte Suprema, existe una impropiedad manifiesta en el debate planteado en estos autos al referirse a la prescripción de la acción de dominio o aludir a la prescripción extintiva de la acción reivindicatoria especial del artículo 26 del decreto ley № 2.695. Este precepto establece: "Sin perjuicio de lo dispuesto en el artículo 19 los terceros podrán, dentro del plazo de un año, contado desde la fecha de la inscripción del inmueble

\footnotetext{
${ }^{1}$ Las acciones de corto tiempo son únicamente aquellas que enumeran los artículos 2521 y 2522 del Código Civil, y son excepcionales, por tanto, no puede llegarse a ellas por vía de analogía.
} 
practicada por resolución administrativa o judicial, deducir ante el tribunal señalado en el artículo 20 las acciones de dominio que estimen asistirles". Explica el tribunal que del texto cabe concluir que se estipula un plazo de caducidad para interponer la acción reivindicatoria especial. "Si transcurre el término de un año sin que el o los terceros hayan reclamado su derecho no podrán ejercer la acción con posterioridad, la que debe entenderse caduca, mas no prescrita. He aquí el problema dogmático que se ha manifestado en la especie. Las acciones de dominio, por ejemplo la reivindicatoria, no prescriben, sino que se extinguen como una consecuencia de la adquisición del dominio por otro sujeto, lo que priva al dueño de la protección dominical. Por lo mismo el demandado de acción reivindicatoria que haya adquirido por prescripción adquisitiva no debe alegar la extinción por prescripción de la acción dominical, sino que debe defenderse alegando que es dueño conforme la prescripción adquisitiva", conclusión con la cual no podemos sino estar de acuerdo nuevamente.

Respecto del fondo de la cuestión debatida es posible sintetizarla en el siguiente interrogante. ¿Era posible interrumpir la prescripción adquisitiva de un año que estaba corriendo con la sola presentación de la demanda o era indispensable para producir tal efecto interruptivo la notificación legal de la misma?

Antes de entrar a lo esencial, describiremos brevemente el segundo fallo de nuestro máximo tribunal que hemos decidido comentar.

\section{Sentencia de la Corte Suprema, rol No 55077-2016, de 9 de noviembre de 2016}

Acá nos encontramos con un caso de prescripción extintiva de una acción ejecutiva, en procedimiento sobre cobro de pagaré, rol No 4478-2015, del Décimo Tercer Juzgado Civil de Santiago, caratulado "Scotiabank Chile S.A. con Meisenbichler Ortega, Gladys Verónica", en el que la parte ejecutada recurre de casación en el fondo en contra de la sentencia pronunciada por la Corte de Apelaciones de Santiago que confirmó el fallo que acogió parcialmente la excepción del número 17 del artículo 464 del Código de Procedimiento Civil opuesta a la ejecución, esto es, la prescripción de la deuda o sólo de la acción ejecutiva.

En cuanto a los fundamentos del recurso, la recurrente sostiene que el faIlo infringe los artículos 98, 100 y 105 incisos $2^{\circ}$ y $3^{\circ}$ de la ley $N^{\circ} 18.092$, en relación al 464 № 17 del Código de Procedimiento Civil y 2514 del Código Civil, aseverando que los jueces erraron al concluir que la obligación se hizo exigible con la sola presentación de la demanda ejecutiva, ya que, en opinión de quien recurre, la cláusula de aceleración de la obligación contenida en el pagaré que funda la ejecución no fue redactada en términos facultativos, sino imperativos, de modo que el término de prescripción debe contarse desde la 
mora en el pago de las cuotas en que debía servirse la deuda². Como ello aconteció el 4 de agosto de 2014, a la fecha del requerimiento de pago, es decir, al 14 de enero de 2016, ya había transcurrido en exceso el lapso previsto en el artículo 98 de la ley № 18.092, debiendo entonces acogerse íntegramente la excepción en referencia y no en forma parcial, como en definitiva aconteció, decisión que fue adoptada quebrantando las normas que menciona el recurso.

La ejecución de la especie se fundó en la falta de pago de tres pagarés, dos de los cuales eran pagaderos a la vista y a cuyo respecto fue acogida la excepción de prescripción de la acción, decisión que no fue impugnada.

En el considerando cuarto se alude a la cláusula de aceleración sobre cuyo alcance imperativo o facultativo es discutido por las partes, señala dicha cláusula "En caso de mora o simple retardo en el pago de todo o parte de cualquiera de las cuotas de este pagaré... el Banco queda facultado para exigir anticipadamente el pago del total de lo adeudado, el que se considerará vencido para todos los efectos legales...", concluyendo nuestro máximo tribunal "que tal convención tiene un carácter facultativo y no imperativo para el ejecutante, por cuanto, más allá de la potestad del acreedor para deducir la acción de cobro lo que, en cualquier caso, sólo constituye el mero ejercicio de un derecho la exigibilidad anticipada de la totalidad de la obligación ha sido entregada a su arbitrio, autorizándolo para demandar el pago íntegro en el evento de la mora, como es lo que ha sucedido en autos".

En conclusión, el fallo determina acertadamente que la cláusula se encuentra redactada en términos facultativos, por lo que era necesario que el demandante evidenciara "su voluntad de ejercer la facultad de acelerar la exigibilidad del crédito al momento de ingresar su demanda a distribución ante la Corte de Apelaciones de la capital, hecho verificado el 26 de febrero de 2015, aunque sólo notificó la acción a la deudora el 13 de enero de 2016, de modo que a esta última fecha ya había transcurrido el lapso previsto en el artículo 98 de la

\footnotetext{
2 En los últimos años se ha distinguido entre cláusulas de aceleración que se encuentran redactadas en forma imperativa o en forma facultativa. Si en su redacción se encuentra algo parecido a la siguiente fórmula: "La falta de pago de las cuotas hará exigible el total de lo adeudado, como si fuese de plazo vencido", estamos frente a una cláusula imperativa que obliga al acreedor a hacerla efectiva. El día del vencimiento es el día en que se dejó de pagar una cuota. En tal sentido, como el artículo 98 de la ley $\mathrm{N}^{\circ} 18.092$ indica que el plazo de prescripción se cuenta desde el "vencimiento del documento", la doctrina jurisprudencial más reciente y con mayor número de fallos sostiene que cuando hay vencimientos sucesivos hay tantos vencimientos como cuotas, en dicha forma, por ejemplo, resolvió la Corte Suprema, en causa rol № 16.093, de 19 de enero de 1991, "La redacción imperativa de una cláusula de aceleración incluida en un pagaré, obliga al acreedor a hacer efectivo el documento tan pronto se produzca el hecho del incumplimiento de una de sus cuotas y, por lo mismo, el día de su vencimiento es aquel en que deja de pagarse la primera cuota, día desde el cual ha contarse el plazo de prescripción del artículo 98 de la ley N 18.092".
} 
ley $\mathrm{N}^{\circ} 18.092$, respecto de aquellas cuotas cuyo vencimiento acaeció entre el 4 de agosto de 2014 y el 4 de enero de 2015, como acertadamente concluyen los jueces, "ya que al tenor de lo que disponen los artículos 2503 y 2518 del Código Civil, la interrupción del término de la prescripción extintiva de la acción de cobro se verifica con la notificación de la demanda".

\section{3. ¿La notificación legal de la demanda debe realizarse dentro del plazo de prescripción de la acción respectiva para que pueda entenderse interrumpida civilmente la prescripción?}

Como puede apreciarse, ambos fallos, aun recayendo en cuestiones diversas, nos llevan a una cuestión común, esto es, a los requisitos necesarios para que se produzca la interrupción civil de la prescripción, institución que, como se sabe, resulta aplicable tanto a la prescripción adquisitiva como a la prescripción extintiva, por disponerlo así los artículos 2503 y 2518 del Código Civil.

La sentencia de la Corte Suprema, rol № 6900-2015, de 31 de mayo de 2016, ha reflotado la antigua discusión doctrinal y jurisprudencial, pues ha sostenido que no es necesario notificar la demanda dentro del plazo de prescripción para interrumpir civilmente la prescripción. En efecto, siguiendo a Domínguez Águila ${ }^{3}$, dicho fallo expresa que debe distinguirse "entre los efectos procesales de la notificación y los aspectos substantivos en que descansa la prescripción, y no separar unos de otros determina aquí que se pretenda exigir que la voluntad interruptiva se haga depender de su conocimiento por el deudor, a pesar que aquella no tiene por qué tener un carácter recepticio. Es verdad que el Código exige luego para mantener el efecto interruptivo que haya una notificación válida; pero no la pide para que ese efecto se produzca inicialmente". Agrega además la sentencia que, no "parece adecuado exigir para la interrupción la notificación de la demanda, la que si bien debe dotarse de consecuencias en el ámbito estricto del derecho procesal al configurar el inicio del proceso, no cabría estimarla un elemento constitutivo de la interrupción civil de la prescripción. Esto se refuerza si consideramos que la notificación no constituye un acto dentro de la esfera única del acreedor, pues queda supeditada su realización a los vaivenes del acto procesal del receptor judicial y la no siempre fácil ubicación del deudor. A esto cabe agregar que el fundamento de la prescripción estriba en sancionar la desidia o negligencia del acreedor en la protección de sus derechos o en el reclamo de los mismos"; en síntesis, se señala que no puede dejarse en manos de un tercero, del receptor judicial, o del mismo deudor, quien puede decidir ocultarse, el que se logre o no producir los efectos interruptivos cuando

3 Domínguez (2009), p. 236. 
ha quedado patente que la inactividad del acreedor ha cesado, lo que se evidencia con la presentación de la demanda, no requiriéndose necesariamente la notificación de la misma.

Por último, la sentencia expresa entre sus argumentos en su considerando quinto, "Queda todavía por considerar que el artículo 2503 № 1 que ha sido el precepto que ha fundado la tesis predominante no señala que deba notificarse dentro del plazo de prescripción para que ésta se entienda interrumpida. Sólo indica que para alegar la interrupción la demanda debe haber sido notificada sin indicar la época en que deba realizarse ni tampoco que deba tener lugar antes de expirar el plazo. Considerado lo anterior es tiempo de variar el criterio mayoritario que ha sostenido que la interrupción de la prescripción requiere la presentación de la demanda y además su notificación aún devengándose el plazo de prescripción. Esta posición doctrinal y jurisprudencial contraviene el fundamento mismo de la prescripción, que sanciona el descuido, desidia y negligencia de quien detenta un derecho y, en cambio, privilegia una interpretación que no tiene asidero en los artículos 2518 y $2503 \mathrm{~N}^{\circ} 1$, ambos del Código Civil" 4 .

Resumiendo, para sostener la tesis antedicha, el primer fallo expuesto ha utilizado los siguientes argumentos:

1. Para interrumpir la prescripción no es necesario que el demandado conozca la demanda, pues la presentación de la misma no es un acto jurídico recepticio, basta que ella haya sido presentada dentro de plazo.

2. La voluntad interruptiva no puede hacerse depender del conocimiento que tenga o no el deudor de la circunstancia de que se ha presentado una demanda en su contra.

3. La notificación de la demanda es un presupuesto procesal de la interrupción civil de la prescripción más no un requisito sustantivo, notificándose la demanda en cualquier momento, antes o después de cumplirse el plazo de

\footnotetext{
${ }^{4}$ Debemos advertir que no es la primera sentencia que sostiene esta tesis, dentro de una línea jurisprudencial que, sin dudar, puede calificarse de minoritaria. Así se ha fallado "la interrupción civil se cuenta desde la presentación de la demanda, y si bien es cierto que sin su notificación ella carece de significado procesal, una vez efectuada la notificación se retrotraen sus efectos a la fecha de la presentación de aquélla. Esta es, por lo demás, la tesis que más se aviene con el espíritu de la institución, ya que es la presentación de la demanda, o sea el acto de reclamar o perseguir su derecho en juicio por parte del acreedor, el evento público y ostensible que pone de manifiesto el propósito del titular del derecho de instar por su resguardo poniendo en conocimiento de la justicia su pretensión en tal sentido. De otra parte, confirma esta interpretación la idea de que los efectos de la interrupción no pueden quedar expuestos a las artes y maniobras del deudor, quien, una vez presentada la demanda interruptoria, podría dilatar o dificultar la práctica de la notificación más allá del vencimiento de la prescripción, impidiendo de esta manera que ella quedara interrumpida con el recurso judicial del acreedor que tiende precisamente a impedir su curso". C. Valparaíso, 29 de octubre de 1963, Rev. de Der., t. 60 , sec. $2^{\text {a }}$, p. 130 , entre muchas otras.
} 
prescripción, se cumple con el requisito procesal para poder invocar la interrupción civil de la prescripción.

4. Los efectos de la interrupción civil de la prescripción no pueden hacerse depender del vaivén de actuaciones ajenas a la esfera de la voluntad del acreedor, como lo es la actuación del tribunal, del receptor judicial, o a la circunstancia de ser habido o no el demandado para ser notificado.

5. El fundamento de la prescripción estriba en sancionar la desidia o negligencia del acreedor en la protección de sus derechos o en el reclamo de los mismos, desidia o negligencia que queda desvirtuada con la sola presentación de la demanda por parte del acreedor o dueño, pues con dicha actuación resulta palmario que el acreedor o dueño ha decidido actuar en defensa de sus intereses.

6. El artículo $2503 \mathrm{~N}^{0} 1^{5}$ no señala que deba notificarse dentro del plazo de prescripción para que ésta se entienda interrumpida, sólo indica que para alegar la interrupción la demanda debe haber sido notificada, sin indicar la época en que deba realizarse ni tampoco que deba tener lugar antes de expirar el plazo.

\section{Los argumentos de la antigua discusión}

La doctrina y la jurisprudencia mayoritaria en Chile se ha inclinado, contrario a lo sostenido por la Corte en el fallo citado en el epígrafe anterior, por exigir que la notificación de la demanda deba hacerse dentro del término de prescripción de la acción ${ }^{6}$, por considerar que el concepto "notificación legal de la demanda" supone que ésta haya sido presentada y notificada dentro del plazo de prescripción, si se quiere producir el efecto de interrumpir civilmente la prescripción en los términos señalados por los artículos 2503 y 2518 de nuestro Código Civil'?

\footnotetext{
${ }^{5}$ Toda referencia a artículos sin indicar el Código de que se trata debe entenderse hecha al Código Civil chileno.

${ }^{6}$ Además de otros requisitos, se acostumbra a exigir que la demanda sea presentada en tribunal competente y que la notificación sea válida y no nula, para poder entender que pueda hablarse de "notificación legal de la demanda".

7 C. Suprema, 9 de abril de 2001, Rev. de Der., t. 98, sec. 1ª, p. 71; 26 de noviembre de 1991, Rev. de Der., t. 88, sec. $1^{a}$, p. 102. En idéntico sentido, C. Pedro Aguirre Cerda, 10 de marzo de 1997, Rev. de Der., t. 94, sec. 2a , p. 28; C. Punta Arenas, 29 de agosto de 1991, Rev. de Der., t. 88, sec. 2a, p. 101; C. La Serena, 7 de octubre de 1910, Rev. de Der., t. 9, sec. 1ª, p. 516, jurisprudencia citada por DomínGuEZ, R., La prescripción..., cit. (n. 1), p. 260. Por su parte, EsCALONA cita las siguientes sentencias: C.A. Concepción, 1 de abril de 1982, Rev. de Der. t. 31, sec. 2a, p. 33; C.A. Santiago, 28 de diciembre de 1961, Rev. de Der. t. 58, sec. 4a, p. 382; C. Suprema, 7 de noviembre de 1958, Rev. de Der. t. 55, sec. $3^{\text {a }}$, p. 17; C. Suprema, 30 de enero de 1985, Rev. de Der. t. 82, sec. $1^{\text {a }}$, p. 6; C. Suprema, 26 de noviembre de 1991, Rev. de Der. t. 88, sec. $1^{\text {a }}$, p. 102. Fallos del Mes, 7 de octubre de 1977, № 227 , p. 291, sent. 1; C. Suprema, 10 de abril de 1929, Rev. de Der. t. 27, sec. 1a, p. 240; C.A. Santiago, 15 de julio de 1937, Rev. de Der. t. 82, sec. 1a , p. 179; C.A. Santiago, 20 de diciembre de 1950, Rev. de Der. t. 48, sec. 2a, p. 3; C. Suprema, 1 de septiembre de 1934, Rev. de Der. t. 32, sec. 1a, p. 6;
} 
buena prueba de tal aseveración es lo expresado en el considerando quinto de la comentada sentencia de la Corte Suprema, rol № 6900-2015, de 31 de mayo de 2016, en la que citando a Domínguez Águila8, se ha señalado "Habrá de reconocerse sin embargo, que en el estado actual de la jurisprudencia ya es regla la que obliga a notificar la demanda antes que el plazo de prescripción haya transcurrido", en igual sentido a la línea jurisprudencial señalada encontramos en doctrina a Alessandri y otros, Abeliuk, Rodríguez Grez, Barcia y Escalona, entre muchos otros autores ${ }^{9}$.

Revisando brevemente a los autores citados que, según hemos dicho, pueden agruparse dentro de la doctrina dominante, Alessandri, refiriéndose esta vez a la prescripción adquisitiva, señala, "El segundo requisito para que haya interrupción de la prescripción es que la demanda entablada por el pretendido dueño sea legalmente notificada al actual poseedor de la cosa. Porque según la ley, el que ha interpuesto el recurso judicial no puede alegar la interrupción si la notificación de la demanda no ha sido hecha en forma legal (C. Civil, art. 2503 , inciso $\left.2^{\circ}, \mathrm{N}^{\circ} 1^{\circ}\right)^{\prime \prime 10}$.

Rodríguez Grez, por su parte, explica que "La 'demanda judicial', a que se refiere el artículo 2518 inciso $3^{\circ}$ del Código Civil, debe hallarse notificada, porque mientras esto no ocurre, no existe 'demanda judicial' propiamente tal, sino un acto unilateral, desconocido por el deudor, que no altera la situación de la relación, manteniéndose todos los efectos del silencio. Lo que señalamos queda de manifiesto a propósito de las excepciones contempladas en el artículo 2503. No obstante existir opiniones divergentes sobre esta materia, a nuestro juicio, es evidente que la sola circunstancia de presentarse la demanda no es suficiente para poner fin al 'silencio de la relación', ya que esta última se encuentra trabada entre deudor y acreedor y no por intermediación de un tribunal de justicia. Si la demanda no se 'comunica' (notifica) al deudor, el silencio se mantiene incólume"11. En sentido similar se pronuncian Abeliuk, Barcia y Escalona ${ }^{12}$.

C.A. Santiago, 3 de julio de 1942, Rev. de Der. t. 40, sec. $1^{\text {a }}$, p. 41; C.A. Santiago, 14 de enero de 1944, Rev. de Der. t. 44, sec. 1a, p. 130; C. Suprema, 8 de agosto de 1931, Rev. de Der. t. 30, sec. 1a, p. 552; C. Suprema, 8 de junio de 1945, Rev. de Der. t. 55, sec. $3^{a}$, p. 17; Rev. de Der. t. 43, sec. ${ }^{\text {a }}$, p. 18; Rev. de Der. t. 48, sec. $2^{\text {a }}$, p. 12. Escalona (1997), p. 185.

${ }^{8}$ Domínguez (2009), p. 263.

9 Alessandri et al. (2004), p. 33. Abeliuk (2008), p. 330 (este autor con reserva). Rodríguez (2008), p. 302; ESCALONA (1997), p. 186, entre muchos otros.

10 AlESSANDRI et al. (2004), p. 36.

11 Rodríguez (2008), p. 302.

12 AbeluUk (2008), p. 330; por su parte, BARCIA señala: "Para que la demanda judicial produzca la interrupción de la prescripción es necesario que ella sea notificada y que la notificación se haya efectuado antes de expirar el plazo de prescripción". BARCIA (2010), p. 204. 
En síntesis, la doctrina y jurisprudencia nacional se decanta por exigir, como requisito de la notificación legal, que ésta se haya efectuado dentro del plazo de prescripción, salvo la doctrina minoritaria representada por la opinión de Domínguez, según se ha dicho, o el caso de Abeliuk, quien no obstante reconocer que la línea dominante en la Corte Suprema es la señalada, advierte que "un fallo reciente de la I. Corte de Santiago sostiene que basta con que la demanda se intente antes de cumplirse el término de la prescripción, aunque la notificación se haga posteriormente, pues ella retrotrae sus efectos a la presentación de la demanda"13.

Peñailillo, por su parte, ofrece una excelente síntesis de los argumentos que se han esgrimido para defender una u otra tesis, pero sin pronunciarse sobre aquella que le parece más adecuada ${ }^{14}$.

\section{Algunas consideraciones adicionales}

No es extraño para la civilística asignar significado a la interposición de la demanda, en tal sentido Flume señala: "La interposición de una demanda puede ser una declaración de voluntad por acto concluyente, y la pretensión que se hace valer en la demanda tiene por presupuesto la emisión de una declaración de voluntad, y de este modo la manera de hacer valer la pretensión mediante

\footnotetext{
${ }^{13}$ Continúa señalando AвецIuk: "Es interesante esta posición, pues si bien se mira la ley ha exigido únicamente demanda judicial, y ha declarado solamente que ella es inapta para la interrupción si no ha sido notificada en forma legal", AвELIuk (2008), p. 330.

14 "Aquí surge una discrepancia (común a ambas prescripciones) sobre la época en que debe notificarse. Para que la interrupción produzca efectos es claro que la demanda debe ser notificada; la duda es si para interrumpir basta presentar la demanda ante el tribunal dentro del plazo o, además, es necesario notificarla dentro de él. La primera solución se funda en que las resoluciones judiciales sólo producen efecto una vez notificadas; $y$, sobre todo, en que conforme al art. 2503 no hay interrupción si no hay notificación; puede añadirse también que lo que queda interrumpida efectivamente es la posesión, la cual con la sola presentación de la demanda no es aún agredida. La segunda se apoya en que la ley exige solamente "recurso judicial" (o "demanda judicial" si se trata de la extintiva, según el art. 2518), idea reafirmada en el art. 2503, al que basta que se haya "intentado" el recurso judicial. A esos argumentos puede agregarse otro de efecto práctico: si se exige que también la notificación se practique dentro del plazo, en la realidad al que quiere interrumpir (dueño o acreedor, según el caso) se le estaría restando plazo; más aún, a algunos se les estaría confiriendo menos plazo que a otros; es así porque, como tiene que preocuparse de notificar, tendría que salir de su inactividad un tiempo antes de vencerse el plazo, y si el demandado es de difícil ubicación, el respectivo actor tendría menos plazo que otro cuyo demandado es de muy fácil notificación (a lo que puede agregarse la posibilidad de que el demandado despliegue maniobras para evadir o postergar la notificación); esa desigualdad no es aceptable y se evita con esta alternativa. Pero sobre estos argumentos específicos, el conflicto puede dirimirse en base a unas apreciaciones institucionales. Por una parte, es útil tener presente una distinción entre los efectos substantivos y procesales de la demanda...". Peñailillo (2010), pp. 182-183.
} 
demanda ya tiene lugar en ejecución de una declaración de voluntad, concretamente la de exigir sus consecuencias jurídicas" ${ }^{\prime 15}$.

Con todo, lo afirmado por Flume sólo nos sirve para dejar asentado que la demanda puede llegar a ser calificada como conducta concluyente -facta concludentia-, para derivar de ella un determinado significado de la conducta, en este caso la voluntad del acreedor o dueño de poner fin a su pasividad en la defensa de sus derechos, pero no nos da luz acerca de si es necesario, para poder tener por logrado dicho efecto, que la demanda sea notificada legalmente, más aún, dentro del plazo de prescripción extintiva de la acción o adquisitiva del derecho de dominio y demás derechos reales.

Sin embargo, aun cuando fuere posible asignar valor jurídico a la conducta consistente en la sola presentación de la demanda, la teoría del acto jurídico presenta sus limitaciones, ya que evidentemente no nos encontramos en presencia de un acto jurídico bilateral, menos ante un acto jurídico recepticio (categoría únicamente aplicable a los negocios jurídicos unilaterales), como alguno pudiera pensar, porque para calificar al acto jurídico unilateral como recepticio no es necesario, como explica Flume, la recepción del destinatario de la declaración de voluntad recepticia, el criterio que nos lleva a la categoría de "recepticio" es que dicha voluntad "Ha de ser emitida frente a otro; en correspondencia se llaman no recepticias aquellas declaraciones de voluntad que no han de ser emitidas a otros"16. Flume responsabiliza de la confusión terminológica a Zitelmann ${ }^{17}$. Lo dicho demuestra la insuficiencia de la teoría del acto jurídico civil en materia procesal para dilucidar el problema que nos hemos propuesto, por lo que, por lo mismo, será necesario recurrir a la teoría de la llamada relación jurídica procesal para determinar si se requiere de notificación legal de la demanda dentro del término de prescripción de la acción, para que se pueda provocar el efecto interruptivo de la misma.

En Derecho procesal es un hecho pacífico que para que se produzca la Ilamada relación jurídica procesal o emplazamiento es necesario la notificación legal de la demanda dentro de plazo. De lo contrario, se darían casos absurdos como los siguientes: con la sola presentación de la demanda se podría entender interrumpido el plazo de prescripción, pero el demandante posteriormente

\footnotetext{
15 Flume (1998), p. 103.

${ }^{16}$ Es lo normal que la declaración de voluntad en un acto jurídico bilateral se realice frente a otro, para eso se realiza, buscando la manifestación del otro con el propósito de lograr la formación del consentimiento. La calidad de recepticia o no, únicamente se plantea en los actos jurídicos unilaterales, en los que, en ocasiones, habrá de determinarse si la declaración de voluntad fue hecha frente a quien se pretenden oponer los efectos del acto jurídico.

17 Citado por Flume (1998), p. 178.
} 
podría retirar la demanda o no notificarla nunca, en estos casos se daría la paradoja de que el plazo de prescripción estuvo interrumpido, pero no produjo ningún efecto, ni nadie se enteró.

Recordemos que la sentencia de la Corte Suprema, rol No 6900-2015, de 31 de mayo de 2016, siguiendo a Domínguez Águila18, ha señalado que no "parece adecuado exigir para la interrupción la notificación de la demanda, la que si bien debe dotarse de consecuencias en el ámbito estricto del derecho procesal al configurar el inicio del proceso, no cabría estimarla un elemento constitutivo de la interrupción civil de la prescripción". Señala que la notificación es necesaria dentro del "ámbito estricto del derecho procesal" y que la notificación no es requisito para la interrupción, sino "un presupuesto procesal para ejercicio", olvidando que el "ámbito estricto del derecho procesal" en materia procesal civil produce consecuencias en Derecho sustantivo, y que la notificación de la demanda dentro de plazo es un requisito indispensable para que se produzca el emplazamiento, y éste, a su vez, es condición esencial para que se produzcan todos y cada uno de los efectos previstos en la ley para los casos en que se exige presentación de la demanda, salvo texto expreso en contrario, requisito en el cual se subentiende incorporado el de la notificación legal de la misma. Rodríguez Papic define el emplazamiento como "una notificación a la cual se le agrega la orden de que el demandado comparezca al tribunal a causa de que hay una demanda interpuesta en su contra o de que se ha deducido un recurso legal"19, posteriormente señala que la notificación legal de la demanda es requisito del emplazamiento, explicando, en lo relativo a sus efectos que: "No basta que la demanda sea notificada, sino que ella debe notificarse en forma legal; si no se notifica en forma legal, no puede producirse la relación procesal entre demandante y demandado y el tribunal; y si el juicio sigue tramitándose, todo lo actuado será nulo, por faltar un presupuesto en la relación procesal, cual es el emplazamiento" ${ }^{\prime 20}$.

Adicionalmente, la sentencia ya tantas veces referida señala como otro argumento para sostener su tesis de la no necesidad de notificar la demanda dentro de plazo para lograr el efecto de la interrupción civil de la prescripción, que "la notificación no constituye un acto dentro de la esfera única del acreedor, pues queda supeditada su realización a los vaivenes del acto procesal del receptor y la no siempre fácil ubicación del deudor. A esto cabe agregar que el fundamento de la prescripción estriba en sancionar la desidia o negligencia del

18 Domínguez (2009), p. 236.

19 Rodríguez (2016), p. 33.

20 Rodríguez (2016), p. 34. 
acreedor en la protección de sus derechos o en el reclamo de los mismos", y para demostrar que esa desidia ha terminado basta la presentación de la demanda, opinión que, como hemos adelantado, no compartimos. Para interrumpir la prescripción es necesario que se produzca el emplazamiento, si eso no se logra dentro del plazo de prescripción, el demandante debe igualmente calificarse de negligente. Al efecto un ejemplo: el demandante ejecutivo tiene tres años para ejercer su acción, si decide hacerlo un mes antes y no logra la notificación, pues el deudor se esconde siendo necesario estampar búsquedas y notificar por el inc. $2^{\circ}$ del artículo 44 del Código de Procedimiento Civil, es lícito preguntarse ¿podremos calificar al actor de diligente? ¿no es mejor en este caso privilegiar la seguridad jurídica? ¿no debió prever el demandante dificultades normales y frecuentes en el proceso de notificación?

Por otra parte, dentro de estas consideraciones finales, recordaremos que Ley № 18.092, sobre Letra de Cambio y Pagaré -de carácter mercantil, y que por lo mismo no puede considerarse estatuto jurídico protector- señala en su artículo 100 que la prescripción se interrumpe sólo respecto del obligado a quien se notifique la demanda judicial de cobro de la letra, o la gestión judicial necesaria o conducente para deducir dicha demanda o preparar la ejecución. Agrega el inciso $2^{\circ}$ que igualmente se interrumpe respecto del obligado a quien se notifique la demanda judicial de cobro de la letra, o la gestión judicial necesaria o conducente para deducir dicha demanda o preparar la ejecución.

Es decir, en esta sede se señala expresamente que la prescripción se interrumpe sólo respecto del obligado a quien se notifique la demanda judicial de cobro de la letra, no siendo suficiente la sola presentación de la demanda, la que debe constituir, a mi entender, la regla general en materia de interrupción de la prescripción en Derecho privado, esto es, que se requiera para entender interrumpida la prescripción la notificación legal de la demanda dentro del plazo interruptivo, habiéndose, como consecuencia, producido el emplazamiento, como institución procesal que tiene claros efectos en Derecho sustantivo.

Con todo, no se puede dejar de observar que nuestro máximo tribunal, en sentencia más reciente, Corte Suprema, rol № 55077-2016, 9 de noviembre de 2016, en su considerando cuarto, se aparta de la doctrina que criticamos volviendo a la que estimamos correcta, al señalar: "No obstante ello, debe considerarse que si bien el demandante evidenció su voluntad de ejercer la facultad de acelerar la exigibilidad del crédito al momento de ingresar su demanda a distribución ante la Corte de Apelaciones de la capital, hecho verificado el 26 de febrero de 2015, sólo notificó la acción a la deudora el 13 de enero de 2016, de modo que a esta última fecha ya había transcurrido el lapso previsto en el artículo 98 de la ley $\mathrm{N}^{\circ} 18.092$ respecto de aquellas cuotas cuyo vencimiento acaeció entre el 4 de agosto de 2014 y el 4 de enero 
de 2015, como acertadamente concluyen los jueces, ya que al tenor de lo que disponen los artículos 2503 y 2518 del Código Civil, la interrupción del término de la prescripción extintiva de la acción de cobro se verifica con la notificación de la demanda".

\section{Conclusiones}

En contra de lo sostenido por la sentencia de la Corte Suprema, de 31 de mayo de 2016, rol No 6900-2015, en el sentido que basta la presentación de la demanda para interrumpir civilmente la prescripción sin que sea necesaria la notificación dentro del término interruptivo, siendo la notificación considerada como un presupuesto procesal para "el ejercicio de la acción", estimamos que la notificación debe efectuarse y completarse dentro del plazo de prescripción por las siguientes razones:

1. Razón de texto. De acuerdo a la remisión que hace el artículo 2518 al 2503 entendemos que la forma legal de hacer la notificación supone que se haga dentro del plazo de la prescripción de la acción respectiva.

2. La presentación de la demanda es un hecho material y unilateral, mientras no se notifique, no produce consecuencia jurídica alguna. Por lo mismo, puede ser retirada cuando lo desee la parte que la ha presentado.

3. Porque, en general, en los estatutos jurídicos protectores -Derecho del consumo y Derecho del trabajo- para proteger jurídicamente a la parte más débil, en este caso consumidores y trabajadores, que serán los actores a los que le interesa interrumpir la prescripción, ha predominado la tesis de que basta la interposición de la demanda, tesis que en este caso se explica por el carácter tutelar de ambas disciplinas, además de que, en el caso del Derecho de consumo, es extremadamente breve del plazo para ejercitar la acción infraccional -seis meses-.

4. Si la ley exime de la notificación dentro de plazo en forma expresa en algunos casos, por ejemplo, en el artículo 54 inciso final de la Ley $\mathrm{N}^{\circ} 15.231$, sobre Organización y Atribuciones de los Juzgados de Policía Local, debe entenderse ésta la excepción. La regla general, a la sazón, sería la contraria, esto es, que la notificación deba hacerse dentro del plazo de prescripción de la acción respectiva.

5. El "ámbito estricto del derecho procesal" en materia procesal civil produce consecuencias en Derecho sustantivo, constituyendo la notificación de la demanda dentro de plazo un requisito indispensable para que se produzca el emplazamiento, siendo éste, a su vez, condición esencial para que se originen todos y cada uno de los efectos previstos en la ley para los casos en que se exige presentación de la demanda, requerimiento en el cual se subentiende incorporado la notificación legal de la misma. 
6. La sola presentación de la demanda no es suficiente demostración de que la negligencia o desidia del acreedor ha cesado, no puede considerarse diligente al actor que ha dejado transcurrir casi todo el plazo de prescripción de la acción, ejerciéndola a última hora, sin prever que la notificación puede presentar demoras, que están previstas en la ley, siendo de ordinaria ocurrencia en la traba de la litis en materia procesal civil.

7. Que la notificación legal de la demanda dentro de plazo, así como su consecuencia: el emplazamiento, sean miradas como integrantes del "ámbito estricto del derecho procesal", así como la circunstancia de que la notificación sea estimada únicamente como un "presupuesto procesal de ejercicio de la acción", independiente del Derecho sustantivo, lo consideramos erróneo. El Derecho procesal civil es un sistema completamente articulado entre el Derecho sustantivo y adjetivo, en donde lo que se haga en uno, sin duda, tendrá consecuencia en el otro.

8. Que desestimar el emplazamiento, que incluye en forma evidente la notificación legal de la demanda dentro de plazo, como el hito que marca el inicio de la relación jurídica procesal, así como todas las consecuencias que de él derivan, tanto en el contorno civil como procesal, es artificioso, no dando cuenta de la realidad sistémica de ambos componentes.

9. La prescripción, tanto adquisitiva como extintiva, tiene su fundamento en la seguridad jurídica entendida, seguridad que se ve abierta y seriamente amenazada si los actores pudieran provocarse artificiosamente una ampliación significativa de los plazos de prescripción, únicamente con la presentación de la demanda. Dicha tesis contradice el fundamento mismo de la prescripción, así como las más elementales consideraciones sobre el inicio de la relación jurídica procesal y sus efectos.

\section{BiBLIOGRAFíA CITADA}

Abeliuk Manasevich, René (2008): Las obligaciones, quinta edición actualizada (Santiago, Editorial Jurídica de Chile).

Alessandri Rodríguez, Arturo; Somarriva Undurraga, Manuel; Vodanovic Haklicka, Antonio (2004): Tratado de las obligaciones (Santiago, Editorial Jurídica de Chile).

Barcia Lehmann, Rodrigo (2010): Lecciones de Derecho Civil chileno. De la teoría de las obligaciones (Santiago, Editorial jurídica de Chile).

Domínguez Águila, Ramón (2009): La prescripción extintiva. Doctrina y jurisprudencia (Santiago, Editorial Jurídica de Chile).

EsCalona Riveros, Francisco (1997): La prescripción extintiva civil (Santiago, Editorial Jurídica ConoSur). 
FLUME, Werner (1998): El negocio jurídico (Madrid, Editorial Fundación Cultural del Notariado).

Peñallillo Arévalo, Daniel (2010): Los bienes. La propiedad y otros derechos reales (Santiago, Editorial Jurídica de Chile).

Rodríguez Grez, Pablo (2008): Extinción no convencional de las obligaciones (Santiago, Editorial Jurídica de Chile).

Rodríguez Papic, Ignacio (2016): Procedimiento civil. Juicio ordinario de mayor cuantía (Santiago, Editorial jurídica de Chile).

\section{JURISPRUDENCIA CITADA}

Vargas Cerpa, Luis Alberto y otros con Marmolejo Fuenzalida, Carlos, Corte Suprema, rol No 6900-2015, de 31 de mayo de 2016.

Scotiabank Chile S.A. con Meisenbichler Ortega, Gladys Verónica, Corte Suprema, rol № 55077-2016, de 9 noviembre de 2016.

\section{NORMAS JURÍDICAS CITADAS}

Código Civil.

Código de Procedimiento Civil.

Decreto ley No 2.695 . 